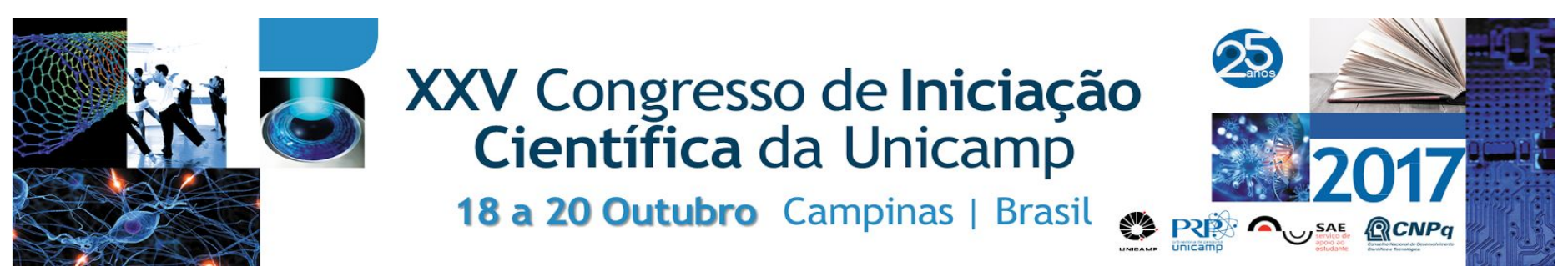

\title{
EVOLUÇÃO DO PERFIL DOS TRABALHADORES INFANTIS NO ESTADO DE SÃO PAULO NO PERÍODO DE 2004 À 2014
}

\author{
lane Souza Silva*, Temidayo James Aransiola.
}

\section{Resumo}

A Organização Internacional do Trabalho (OIT) e especialistas brasileiros sobre trabalho infantil estão em consenso de que a redução do número de crianças e adolescentes que trabalham no Brasil chegou no seu "núcleo duro". Este se refere a um ponto em que a erradicação se torna mais difícil e demanda novas estratégias de ação. Tal dificuldade resulta na redução, cada vez menos acentuada, da taxa de trabalho infantil. Para averiguar as causas dessa inércia, é necessário conhecer tanto o perfil dos trabalhadores infantis como a evolução do mesmo. Por este motivo, esse projeto se propõe a determinar e analisar a evolução do perfil dos trabalhadores infantis no estado de São Paulo durante o período de 2004 à 2014. A estratégia de pesquisa será de tabulação e análise descritiva dos microdados da PNAD.

\section{Palavras-chave:}

Trabalho infantil, Evolução, São Paulo.

\section{Introdução}

A taxa de trabalho infantil no Brasil apresentou, ao longo da última década, uma tendência de queda expressiva, porém, ao passar do ano de 2013 para 2014, houve aumento de cerca de $4,5 \%$ (conforme microdados da PNAD). Na mesma década, o estado de São Paulo apresentou reduções tímidas na taxa de trabalho infantil, comparada àquela observada para o país como todo. Logo, surge uma pergunta principal: por que a intensidade de redução da taxa de trabalho infantil no estado de São Paulo não acompanha a intensidade de redução observada para o país como todo? Esse estudo, com o intuito de responder tal pergunta, se depara com uma segunda questão: quais as peculiaridades do perfil dos trabalhadores infantis no estado de São Paulo comparado ao dos trabalhadores infantis no país como um todo? A resposta desta última pergunta será a chave para inferir a respeito da questão principal.

Em virtude dos desafios enfrentados por políticas públicas para reduzir a taxa de trabalho infantil nas regiões metropolitanas do Brasil, devido às constantes evoluções do perfil dos trabalhadores infantis e as atividades nas quais os mesmos estão envolvidos, o principal objetivo desse projeto é: investigar a evolução do perfil dos trabalhadores infantis no estado de São Paulo no período de 2004 à 2014.

\section{Resultados e Discussão}

Os dados utilizados para cumprir os objetivos propostos nesse projeto foram extraídos dos microdados da Pesquisa Nacional por Amostra de Domicílios (PNAD), organizada pelo Instituo Brasileiro de Geografia e Estatística (IBGE). Esses dados são referentes ao período de 2004 à 2014 e são do estado de São Paulo. O método de pesquisa é, basicamente, análise de médias, frequências e proporções dos dados tabulados.
A partir das análises, verificou-se que a taxa de trabalho infantil de São Paulo vem diminuindo ao longo dos anos, no entanto, de maneira retraída. Isto ocorre devido às evoluções observadas no perfil dos trabalhadores infantis, o que implica que as soluções políticas não estão atingindo onde e quem deveriam. Neste sentido, os resultados das análises desse projeto contribuem para o delineamento do que seria o perfil dos trabalhadores infantis do estado de São Paulo.

Figura 1. Evolução da taxa de trabalho infantil no Brasil e no Estado de São Paulo (2004 - 2014).

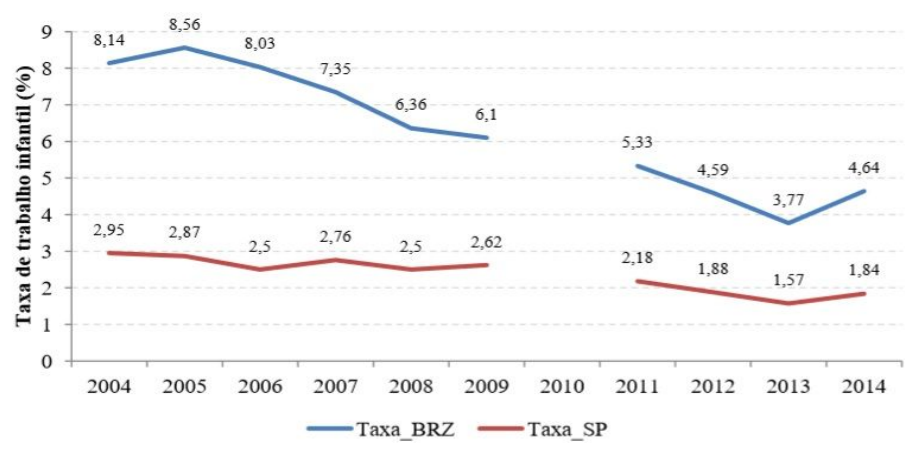

\section{Conclusões}

A grande maioria dos trabalhadores infantis do estado de São Paulo são: meninos; pertencem à zona urbana; estão trabalhando nos setores de comércio e de serviços; e, trabalham e estudam.

KASSOUF, A. L. Evolução do trabalho infantil no Brasil. Sinais Sociais, Rio de Janeiro, v.9, n. 27, p. 9-45, jan.-abr. 2015.

MARIA, I.; CARVALHO, M. De. O trabalho infantil no Brasil contemporâneo. CADERNO CRH, Salvador, v. 21, n. 54, p. 551-569, Set.-Dez. 2008.

ZANCAN, N. Determinantes do trabalho infantil no Brasil: Um estudo da tendência de 1992 a 2009. USP, São Paulo, 2011. 